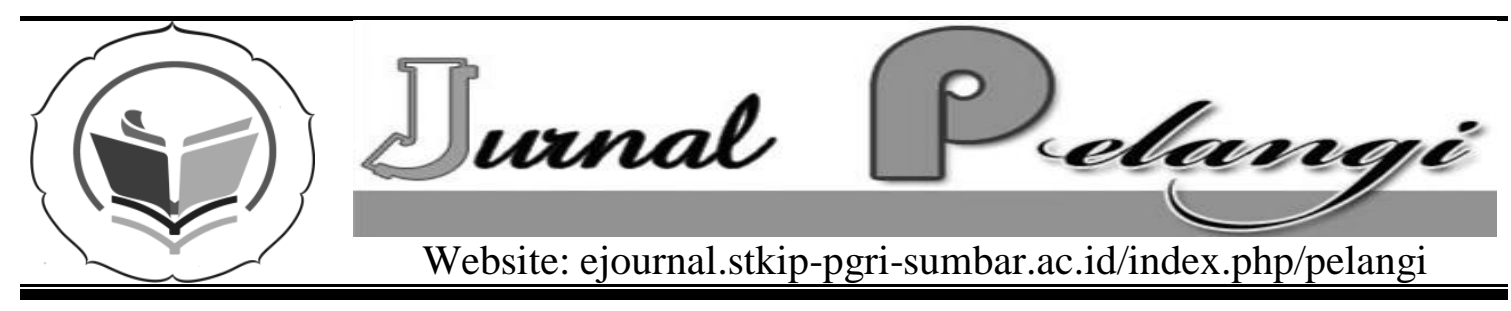

\title{
CONSTRUCTING VALIDITY OF READING COMPREHENSION TEST
}

\author{
Yulmiati \\ STKIP PGRI Sumatera Barat \\ zulfaeva75@gmail.com
}

\section{INFO ARTIKEL}

Diterima:

Direview:

Disetujui:

Kata Kunci:

Pemahaman

Bacaan, Tes, Validitas

\section{INTRODUCTION}

English has been taught as the important subject in Junior High School. According to Peraturan Menteri

\section{Abstrak}

Salah satu instrumen untuk mengukur kompetensi siswa adalah tes.Karena itu perlu bagi guru/pembuat tes untuk mengetahui validitas tes yang diberikan kepada siswa. Namun hal ini sering terabaiakan, buktinya jarang sekali guru mengevaluasi apakah tes yang diberikan kepada siswa valid atau tidak. Akhirnya tes yang diharapkan untuk mengukur kemampuan siswa kurang bisa dijadikan acuan untuk menentukan hasil belajar. Oleh karena itu, peneliti melakukan penelitian yang berkenaan dengan menentukan validitas tes agar bisa dijadikan acuan bagi guru dalam menjalankan prinsip-prinsip yang standar dalam menilai kompetensi siswa. Jenis penelitian ini adalah penelitian deskriptif dengan melakukan proses validasi terhadap tes yang akan diberikan kepada siswa. Analisis data yaitu dengan menggunakan tabulasi data menurut Riduwan (2005: 89). Dalam menentukan validasi, peneliti menggunakan tes reading comprehension untuk semester satu kelas VIII SMP yang dikembangkan oleh peneliti sendiri. Dari analisis data diperoleh hasil validitas isi 87,5, validitas kostruk 77,3 dan validitas muka 87.5 dengan rata-rata 84.1. Hal ini berarti tes dapat diimplementasikan dengan sedikit revisi. Hasil penelitian ini dapat direkomendasikan kepada para pembuat tes/guru agar bisa dijadikan sebagai acuan untuk mengetahui validitas tes yang dibuat/dikembangkan.
Pendidikan Nasional (Permen Diknas) number 22 year 2006, there are three purposes of learning English at Junior High School students, these purposes are 
a) the students are expected to have the competency to communicate orally and written. b) the students know how important English is in improving the quality of Indonesian human resource, and c) the students are expected to understand about the relationship between the language and the culture. Skills in English instruction that should be mastered by the students in school are reading, speaking, writing, and listening. Reading is the activities that mostly done in learning process, because the materials studied in Junior High School are commonly in the form of written text. In reading competence, the students should comprehend what the texts about. According to Howards (1980: 161), there are some causes of reading and language problems in instruction. The most serious problem is in testing and diagnosing student's ability. Many tests are not compatible nor are they comparable in what they are measuring, how they measure it, and how these data can be logically interpreted. This problem also happens in our schools today. In fact, the tests given for Junior High School students are almost never evaluated whether the tests are valid or not. Many mistakes can be found on the test given to students. As the result, it will make the students confuse to answer the test. Automatically the students will be damaged by this case. So, it is better for teachers or test maker to improve their knowledge in developing a test. This opinion is supported by Brown (2004: ix). He states that language teachers have to think about the best way to assess learners' ability and language teachers need to improve their knowledge of how to write a better test. Based on the problem above, the researcher wanted to conduct the research entitled Constructing Validity of Reading Comprehension Test for the first Semester of Grade VIII at Junior
High School in Padang. It is hoped that this research can help the teachers to construct the validity of reading comprehension test in the classroom. So, the test can reflect the ability of the students in reading comprehension.

\section{REVIEW OF THE RELATED THEORIES}

Reading Comprehension

The concept of reading should be known in studying reading comprehension. There are various definitions proposed by some experts. Harris (1980: 3) states that reading is the act of responding with appropriate meaning to printed verbal symbols. For the beginners, reading is mainly concerned with learning to recognize the printed symbols and to respond it intellectually and emotionally. Then, Harris (1980: 3) adds that reading is very complex process in which the recognition and comprehension of written symbols that influenced by the perceptual skills, the word analysis skills, the experience, the language background, the mind set, and the reasoning ability of the reader as he anticipates meaning on the basis of what he has just read. Harris (1980: 9) states that skills in reading comprehension include: acquisition of a rich, extensive, and accurate vocabulary, ability to grasp the meaning of units of increasing size; phrase, sentence, paragraph, whole selection, ability to find answer to specific question, ability to select and understand main idea, ability to note and recall details, ability to grasp the organization of the author's plan, ability to follow directions accurately, ability to evaluate what one reads, and ability to remember what one has read.In addition, Young (1982: 74) states that comprehension focuses on reading instruction, such as: 1) understanding 
words and building vocabulary, 2) understanding sentences, sentences structure, and syntax, and 3) understanding paragraph. Raphael (1986) identifies four levels of comprehension questions, they are right there, think and search, author and me, and on my own. Right There requires you to go back to the passage and find the correct information to answer the questions, example: Who is...?, Where is...?, When is...? How many...?, When did...? Think and Search usually requires you to think about ideas or information in the passage related to each other. The answer is in the text, but the readers have to think and search to find the answer. Example: For what reason...? How did...?, How was...?, Why was....?, What cause...? Author and $\mathrm{Me}$ requires you to use ideas and information that is not stated directly in the passage to answer the questions. These questions require you to think about what you have read and formulate your own ideas or opinions. Example: Which character ...? What do you think...?, Did you agree with...?, Would you ....? On my Own finds the answer from the students' prior knowledge. Answers do not require information from the text but do require the students to make some types of judgment about relate to the topic of the text. Example: Do you know...? , Have you ever ....? Would you ever...? Based on some opinions above, it can be concluded that reading comprehension is one's ability to comprehend the message by understanding the topic, main idea and supporting detail that included on English text. Without comprehension, the reader has difficulties in getting information from a written text or material as interaction between the reader and the text.

\section{Teaching Reading in school}

O’Malley (1996: 94) states that two differences between first and second language reading can be found in the language proficiency and experiences of the students. Student reading in a second language has varied levels of language proficiency in that language. The second language learner may be in the process of acquiring oral language and also responding literacy skills in English. There are two genres of the text that are taught for the first semester of grade VIII at Junior High School determined by Depdiknas (2006), they are: recount and descriptive. Recount text tends to retell events for informing or entertaining in a story. It has some language features such as; focus on individual participants, use of past tense, and focus on a temporal sequence of events. Meanwhile, descriptive text tends to describe a particular person, place or thing in factual context. This texts focus on specific participants, use of attributive and identifying processes frequent use of epithets and classifier in nominal groups, and use of simple present (Gerot and Macken in Hartono, 2005: 6 - 9).

\section{Test}

In order to avoid misperception, there are some theories that can be used in developing test. Nitko (1996: 6) states that a test is an instrument or systematic procedure for observing and describing one or more characteristics of a student using either a numerical scale or a classification scheme. According to Brown (2004: 3) a test, in simple terms, is a method of measuring a person's ability, knowledge, or performance in a given domain. By this definition, it can be said that a test is a method, a test must measure and a test and a test measures an individual's ability, knowledge or performance. Brown (2004:4) states that test are administrative procedures that occur at identifiable times in a 
curriculum when learners muster all their facilities to offer peak performance, knowing that their response are being measured and evaluated. Furthermore, Alderson (1995: 11 - 12) identifies some purposes of the test: placement, progress, achievement, proficiency, and diagnostic. Placement tests are designed to assess students' level of language ability so that they can be placed in the appropriate course or class. Progress tests are given at various stages throughout a language course to see what the students have learnt. Achievement test is designed based on the course syllabus or the course text book that given in at the end of the course. Proficiency tests are designed to test the ability of students with different language training backgrounds. Diagnostic tests seek to identify those areas in which a student needs further help. In addition, Savignon (1983:232) suggests that the test behavior is a true reflection of the underlying competence the tests designed to evaluate. For example, performance on a driving test in fact requires driving ability, performance on a reading test requires reading ability, etc. In other words, the test is valid.

\section{Validity}

Henning (1987: 89) defines validity refers to the appropriateness of a given test or any of its component parts as a measure of what it is purported to measure. A test is said to be valid to the extent that it measures what it is supposed to measure. Then, Alderson (1995: 6) adds validity relates to the uses made of test scores and the ways in which test scores are interpreted, and is therefore always relative to test purpose. Validity can be established in different ways. It is best to validate a test in as many ways as possible. Commonly the types of validity are content, construct, and face validity. Content validity is how well the sample of test tasks represents domain of tasks to be measured. Construct validity is how well test performance can be interpreted as a meaningful measure of some characteristic or quality. Face validity refers only to the appearance of the test (Gronlund, 1985: 58). Alderson (1995: 172 - 185) suggests content validation involves gathering judgment of 'experts': people whose judgment one is prepared to trust or believe. The form of construct validation proceeds mush as content validation: experts are selected, given some definition of the underlying theory, and asked to make judgments after an inspection of the test its construct validity. Meanwhile data on face validity may be gathered by interviewing students or asking them to complete questionnaire about their attitudes and reaction to, and their feelings about, a test they just taken or looked at. Gronlund (1985: 79-82) identifies some factors that influence validity are from test itself, functioning and teaching procedures, factors in test administration and scoring, pupil's responses, and nature of the group and the criterion. In developing the test, it is important to refuse some factors that cause lower validity, they are unclear direction, reading vocabulary and sentence structure too difficult, inappropriate level of difficulty of the test item, poorly constructed test items, ambiguity, test items inappropriate for the outcomes being measured, test too short, improper arrangement of items, and identifiable pattern of answers. Related to factors influencing the validity above, Gronlund (1985: 82) suggests concerning the validity of the test interpretations, it should be considered to know how well the test fits the particular use, how well the testing conditions were controlled, and how 
typical the responses were to the testing situation.

\section{Reading Comprehension Test}

Croft (1980: 495) states one of the important uses of the reading test is to ascertain the degree of reading comprehension of selected material by individuals. He suggests considering the following questions when writing test items for reading comprehension. 1) Is the item, taken as a whole, specific? 2) Is the problem stated briefly? 3) Are the distracters important, plausible answers rather than obviously wrong? 4) Are all alternatives as well as the correct responses parallel in structure? Hughes (1984: 154 - 155) suggests practical advices on writing the item of reading test: 1) presents items in order in which the answers can be found in the text. 2) Do not write items for which the correct response can be found without understanding the text. 3) Do not include items that some candidates are likely to be able to answer from general knowledge without reading the text. 4) Make the items independent of each other. 5) Be prepared to make minor changes to the text to improve an item.

\section{RESEARCH METHODOLOGY}

Type of the Research The type of this research was a descriptive research. Gay and Airasian (2000: 27) state that descriptive research determines and describes the way thing are. This research was intended to determine and describe about the way to construct validity of reading comprehension test, especially for the first semester of grade VIII at Junior High School in Padang.

\section{Research Procedure}

In constructing validity, the researcher used the reading test that developed by the researcher itself. It was
Achievement test of reading comprehension for the first semester of grade VIII Junior High School in Padang. After developing the test, the researcher asked three colleagues or teachers to share and then consulted it with two experts. They were linguistics expert and language educational expert. There are three kinds of validation that should be conducted;

1. Content validation, to see if the assessments accurately reflect the syllabus on which it was based.

2. Construct validation, to see if the assessments reflected accurately the principles of a valid theory of foreign language learning.

3. Face validation, to see how the assessments were look right and appear to measure the knowledge.

The researcher collected the judgments of the experts by using validation checklist and discussion until achieving the valid results. The discussion was commonly focused on answering the questions below:

1. Can the tests assess reading comprehension of the students?

2. Are the tests valid in content?

3. Are the tests valid in construct?

4. Are the tests valid in face?

\section{Instrumentation}

The instrument used in this research was validation checklist. The validation checklist consisted of the items that show content, construct and face validity Acco ding to Arikunto (1999), checklist is the list of statement where the respondents put the checklist sign $(\sqrt{ })$ in the required column. The items of the test were designed based on the indicators and sub-indicators of variables of the research. They were 
reading comprehension and test. The indicator of the research variables can be seen in table 1:

\begin{tabular}{|l|l|l|}
\hline Variables & Indicators & Sub-indicators \\
\hline \multirow{4}{*}{$\begin{array}{c}\text { Reading } \\
\text { Comprehension }\end{array}$} & Understandingtopic & - What is the text about \\
\cline { 2 - 3 } & Understanding main & - Explicitmain idea \\
& idea & - Implied main idea \\
\cline { 2 - 4 } & $\begin{array}{l}\text { Understanding } \\
\text { supportingdetails }\end{array}$ & $\begin{array}{l}\text { - How does the author } \\
\text { support, explain or } \\
\text { provemainidea }\end{array}$ \\
\hline \multirow{2}{*}{ Test } & Valid & $\begin{array}{l}\text { - Content } \\
\text { - Constructs } \\
\text { - Face }\end{array}$ \\
\hline
\end{tabular}

In order to determine the validity of the tests, the researcher conducted validation process and discussion with experts. The data was collected based on the following validation checklist:

Technique of Data Collection

\section{VALIDATION CHECKLIST}

School : Junior High School (SMP)

Subject : English

Skill : Reading Comprehension

As salamu'alaikum, Wr. Wb,

In order to determine the validity of the developed test, Ihope you validate them in this validation checklist. You can put the checklist sign $(\sqrt{ })$ in the required column based on your opinion.

Notes: $0=$ invalid

1 = poorly valid

2 = fairly valid

$3=$ valid

$4=$ very valid

\begin{tabular}{|c|c|c|c|c|c|c|}
\hline \multirow{2}{*}{ Aspect } & \multirow{2}{*}{ Indicator } & \multicolumn{5}{|c|}{ Score } \\
\hline & & 0 & 1 & 2 & 3 & 4 \\
\hline Content & $\begin{array}{l}\text { 1. The items are based on basic } \\
\text { competence and indicator } \\
\text { 2. All items relate to the } \\
\text { instructional objectives and } \\
\text { desiredleaming outcomes. } \\
\text { 3. The alternatives are homogeny } \\
\text { and logic } \\
\text { 4. Every item has one correct } \\
\text { response (for multiple choice) } \\
\text { 5. The items are accordance with } \\
\text { reading comprehension parameter } \\
\text { 6. The results give a broad picture of } \\
\text { the student's reading } \\
\text { comprehension }\end{array}$ & & & & & \\
\hline Construct & $\begin{array}{l}\text { 7. The directions for the overall test } \\
\text { and each section are clear }\end{array}$ & & & & & \\
\hline
\end{tabular}



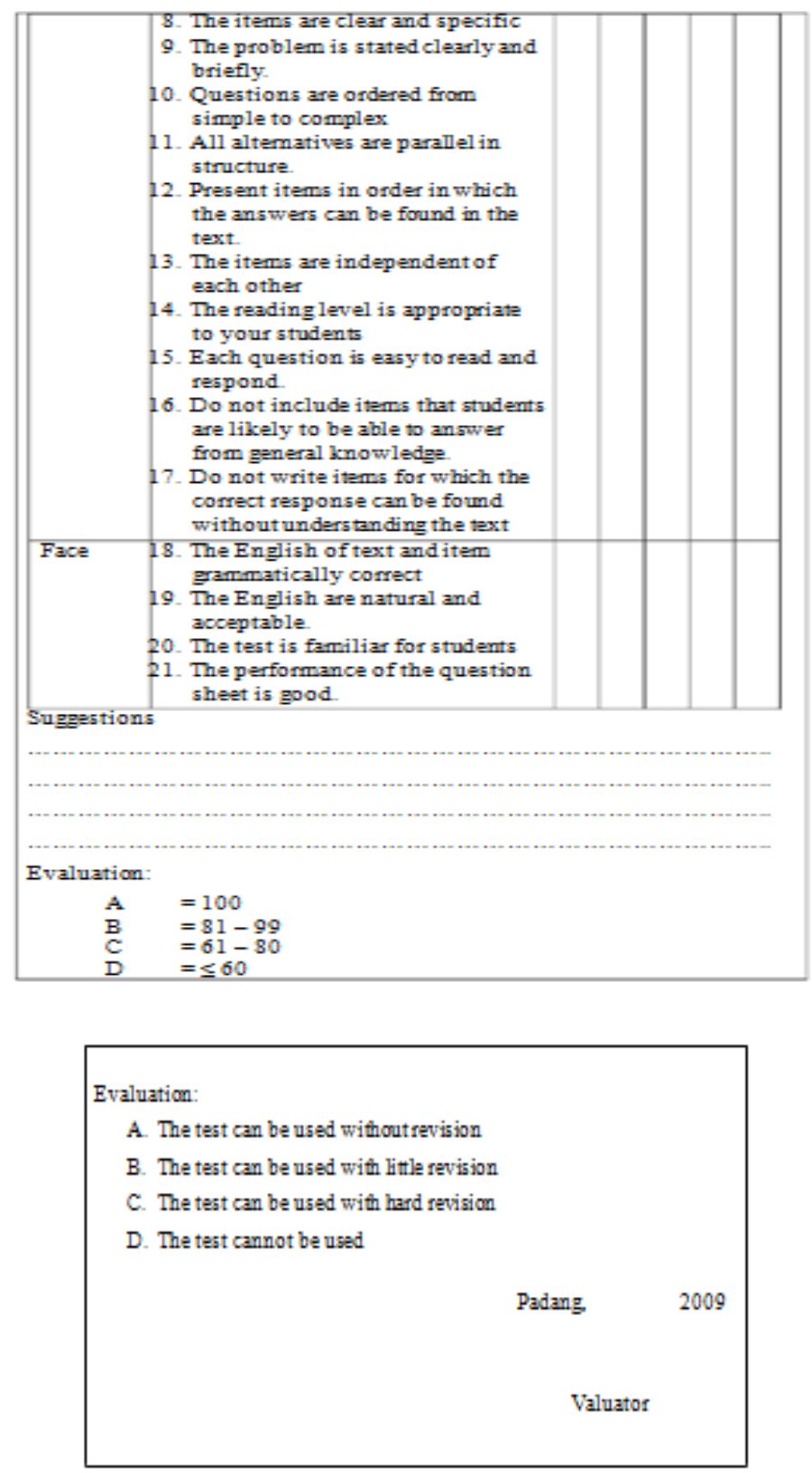

Techniques of Data Analysis The analysis of content, construct, and face validity was based on validation checklist. The validation data were tabulated. The tabulation result was represented by using percentage with the following formula:

Table 2: The validity category of reading comprehension test 


\begin{tabular}{|l|l|}
\multicolumn{1}{|c|}{$(\%)$} & \multicolumn{1}{c|}{ Category } \\
\hline $0-20$ & Invalid \\
\hline $21-40$ & Poorly valid \\
\hline $41-60$ & Fairly valid \\
\hline $61-80$ & Valid \\
\hline $81-100$ & Very valid \\
\hline
\end{tabular}

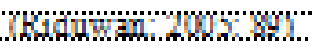

\section{FINDINGS AND DISCUSSION}

\section{Findings}

Validation activities involved content, construct, and face validation were done by two experts theoretically and empirically. After the advisors checked the prototype developed, the researcher revised it, and then the test was validated by two experts. They are linguistics expert and language educational expert. The linguistics expert is Prof. Dr.Jufrizal, M.Hum. The language educational expert is Darmayenti, M.Pd. Then, the researcher analyzed the list in table 3.

\begin{tabular}{|c|c|c|c|c|c|c|}
\hline \multirow{2}{*}{ Aspect } & \multirow{2}{*}{ Indicators } & \multicolumn{2}{|c|}{ Valuators } & \multirow[t]{2}{*}{ Sum } & \multirow{2}{*}{ Total } & \multirow{2}{*}{ Percentage } \\
\hline & & 1 & 2 & & & \\
\hline \multirow{6}{*}{ Content } & 1 & 3 & 4 & 7 & 42 & 87.5 \\
\hline & 2 & 3 & 4 & 7 & & \\
\hline & 3 & 3 & 3 & 6 & & \\
\hline & 4 & 4 & 4 & 8 & & \\
\hline & 5 & 3 & 4 & 7 & & \\
\hline & 6 & 3 & 4 & 7 & & \\
\hline \multirow{11}{*}{ Construct } & 7 & 4 & 3 & 7 & 68 & 77.3 \\
\hline & 8 & 2 & 3 & 5 & & \\
\hline & 9 & 3 & 3 & 6 & & \\
\hline & 10 & 4 & 4 & 8 & & \\
\hline & 11 & 2 & 3 & 5 & & \\
\hline & 12 & 3 & 3 & 6 & & \\
\hline & 13 & 3 & 3 & 6 & & \\
\hline & 14 & 3 & 4 & 7 & & \\
\hline & 15 & 2 & 3 & 5 & & \\
\hline & 16 & 3 & 3 & 6 & & \\
\hline & 17 & 3 & 4 & 7 & & \\
\hline \multirow{6}{*}{ Face } & 18 & 3 & 3 & 6 & & \\
\hline & 19 & 3 & 3 & 6 & 28 & 87.5 \\
\hline & 20 & 4 & 4 & 8 & & \\
\hline & 21 & 4 & 4 & 8 & & \\
\hline & Sum & 65 & 73 & 138 & 151 & 252.3 \\
\hline & Score & \multicolumn{5}{|c|}{84.1} \\
\hline
\end{tabular}

From table 3 , it can be seen that validation score is 84.1 . Based on the validity criteria, it was B category. It means that the test could be used by doing little revision. The revisions of the test can be seen in table 4 . 
Table 4: The revision of test by experts

\begin{tabular}{|c|c|c|c|}
\hline No & Items & Before revision & After revision \\
\hline 1. & $\begin{array}{l}\text { Revising the } \\
\text { paragraph of the } \\
\text { descriptive text }\end{array}$ & $\begin{array}{l}\text { What is the } \\
\text { invitation for? } \\
\text { (Num } 13 \text { ) } \\
\text { To whom is the } \\
\text { message } \\
\text { delivered?(Num 19) }\end{array}$ & $\begin{array}{l}\text { Carolina Beach is a } \\
\text { famous beach in } \\
\text { Padang. The place is } \\
\text { very beautiful and } \\
\text { romantic. You can } \\
\text { spend your time in this } \\
\text { place to enjoy the } \\
\text { charm of the beach. } \\
\text { Whom is the invitation } \\
\text { for? } \\
\text { Whom is the message } \\
\text { delivered to? }\end{array}$ \\
\hline 3. & $\begin{array}{l}\text { To simplify the } \\
\text { sentence of the } \\
\text { item on number } \\
23 \text {, }\end{array}$ & $\begin{array}{l}\text { For what reason } \\
\text { didn't the writer } \\
\text { and the shepherd } \\
\text { finish shearing the } \\
\text { sheep until the next } \\
\text { day? }\end{array}$ & $\begin{array}{l}\text { Why didn't they finish } \\
\text { shearing the sheep } \\
\text { until the next day? }\end{array}$ \\
\hline 4 & $\begin{array}{l}\text { Functional text } \\
\text { (Announcement) }\end{array}$ & $\begin{array}{l}\text { Each class } \\
\text { represents five } \\
\text { contestants }\end{array}$ & $\begin{array}{l}\text { Each class is } \\
\text { represented by five } \\
\text { contestants }\end{array}$ \\
\hline 5 & \multicolumn{3}{|c|}{$\begin{array}{l}\text { Change invitation of wedding party into birthday party, because } \\
\text { invitation of birthday party is mostly found in students' real life } \\
\text { rather than invitation of wedding party. }\end{array}$} \\
\hline
\end{tabular}

\section{Discussion}

Based on validation data analysis by two valuators, it shows thatvalidity of reading comprehension test developed was categorized valid incontent, construct, and face. It means that this test can be implemented with little revision. It shows that reading comprehension test developed can measure what it is supposed to measure. Here was the valuators' comments about reading comprehension

test developed:

1. You need to revise some grammatical problems and mechanic of writing in texts (see correction)

2. Please consider few connections for item test (see corrections)

\section{Conclusion}

Related to the formulation of the problem, research methodology, data analysis and discussion, it can be concluded that:
A. The researcher has conducted data description and analysis based on validation result by the experts. Reading comprehension test developed was valid in content, construct and face. It can be implemented in English class.

B. It is suggested for English teachers, while developing the test for student, to consider the validity (content, construct and face) of the test.

C. It is suggested for English teachers to improve the knowledge about test development, because it can help the teacher to conduct a good test.

\section{BIBLIOGRAPHY}

Alderson, Charles. 1995. Language Test Construction and Evaluation. New York: Cambridge University Press. 
Arikunto, Suharsimi. 1999. Dasar-dasar Evaluasi Pendidikan. Jakarta: Bumi Aksara.

Brown, Douglas. 2004. Language Assessment. Principles and Classroom Practice. San Francisco: Pearson Education, Inc.

Croft, Kenneth. 1980. Reading on English as a Second Language. Boston: Little, Brow and Company

Depdiknas. 2006. Standar Isi Untuk Satuan Pendidikan Dasar dan Menengah. Jakarta. Depdiknas

Gay \& Airasian. 2000. Educational Research: Competencies For Analysis and Application. New Jersey: Prentice Hall, Inc.

Gronlund, Norman. 1985. Measurement and Evaluation in Teaching. New York: Macmillan Publishing Company.

Harris, Albert. 1980. How to Increase Reading Ability. New York: David McKAY Company, Inc.

Hartono, Rudi. 2005. Genres of Texts. Semarang: Unpublished. English Departement of Semarang State University..

Henning, Grant. 1987. A Guide to Language Testing: Development, Evaluation, Research.

Massachusetts: Newbury House Publisher.
Howards, Melvin. 1980. Reading Diagnosis and Instruction. An Integrated Approach. Virginia: Reston Publishing Company, Inc.

Hughes. Arthur. 1984. Testing For Language Teachers. Second Edition. New York:Cambridge University Press.

Nitko, Anthony J.1996. Educational Assessment of Students. New Jersey: Prentice-Hall, Inc.

O’Malley, Michael.1996. Authentic Assessment for English Language Learners. Reading, Mass.: AddisonWesley Publishing Company.

Raphael, T. 1986. Teaching Question Answer Relationship. Revisited. Th reading Teacher. Vol.39 (6), 516 522.

Riduwan. 2005. Belajar Mudah Penelitian Guru, Karyawan dan Peneliti Pemula. Bandung: Alfabeta. Young, Rosalie. 1982. Better Learning: How to Help Students of All Ages Overcome Learning Problems and Learning Disabilities. New Jersey: Prentice-Hall, Inc. 